\title{
FILOZOFIA, HUMANISTYKA I NAUKI SPOŁECZNE - WEZWANIE DO OFENSYWY
}

\begin{abstract}
Agnieszka Lekka-Kowalik, Filozofia, humanistyka i nauki społeczne - wezwanie do ofensywy [Philosophy, the humanities and social sciences - a summons to go on the offensive], edited by Z. Drozdowicz, S. Sztajer ,",Człowiek i Społeczeństwo", vol. XXXIX, Poznań 2015, pp. 87-102. Adam Mickiewicz University Press. ISBN 978-83-232-2953-7, ISSN 0239-3271.
\end{abstract}

The paper aims at justifying a call to go on the offensive in order to assure for philosophy, the humanities and social sciences a proper place in science as a whole. Against the background of the contemporary social context (transdisciplinary research, seeing science as a source of risks, rejection of a liner model of getting social benefits from basic sciences, recognizing stakeholders' participation in research) the Author shows that any research project on life problems cannot be executed by natural or technical sciences alone, but it must engage philosophy, the humanities and social sciences. The same is true of applications of accepted solutions. The conclusion is that cooperation between natural, technical and social sciences, philosophy and the humanities is necessary in doing research and using its achievements. It is also required in education, if scientists and citizens are to act as stakeholders in democratic processes of shaping techno-scientific progress.

Agnieszka Lekka-Kowalik, Katolicki Uniwersytet Lubelski Jana Pawła II, Wydział Filozofii, Instytut Filozofii, Al. Racławickie 14, 20-950 Lublin, Poland

\section{Wstęp}

Tytuł niniejszego artykułu ma dwa założenia, które wyznaczają jego cel i strukturę. Po pierwsze, filozofia, humanistyka i nauki społeczne stoją na pozycji, która jest „poniżej” ich poznawczych i społecznych możliwości; po drugie, istnieją wystarczające racje, by wymienione typy nauk przeszły do ofensywy, aby zdobyć swój „właściwy” status. Nie chodzi mi tu o liczbę 
studentów czy pracowników naukowych, ale o status epistemiczny w świetle rozumienia roli i miejsca nauki w społeczeństwie. Przedstawienie kontekstu i uzasadnienia tytułowego wezwania do ofensywy stanowi zasadniczy cel niniejszego artykułu. Będę starała się więc odpowiedzieć na następujące pytania: 1. Jaki jest współczesny kontekst uprawiania nauki? 2. Jaki jest status i role wymienionych w tytule typów nauk w badaniach nauk przyrodniczych i technicznych? 3. Dlaczego konieczna jest współpraca, a nawet symbioza, nauk przyrodniczych, technicznych, społecznych, humanistycznych i filozofii? 4. Na czym miałaby polegać „ofensywa” i czy gdzieś już się rozpoczęła? Będę zatem rozważać relację filozofii, humanistyki i nauk społecznych do szeroko rozumianych nauk przyrodniczych i technicznych. Mutatis mutandis rozważania te można odnieść do nauk medycznych, farmaceutycznych, weterynaryjnych czy biotechnologii. Jest to rozumienie bardziej potoczne niż formalnoprawne, o którym będzie mowa poniżej.

Rozważania te wpisują się w nurt filozoficznej refleksji nad nauką nazwany filozofią nauki społecznie istotną (socially relevant philosophy of science). Zwolennicy tego nurtu twierdzą:

Widzimy szansę, by wyśmienite prace z zakresu filozofii nauki miały większy wpływ na praktyki i rezultaty badań naukowych. Widzimy też szansę, by filozofowie nauki wspomagali naukowców w rozwijaniu badań, które są istotne dla polityk (policy), a które zarazem zachowują epistemiczny rygor i są wrażliwe na etyczne i polityczne potrzeby większej części społeczeństwa, tak lokalnie, jak i globalnie ${ }^{1}$.

Tak właśnie widzę rolę niniejszego tekstu.

\section{Zmiana kontekstu uprawiania nauki}

Warto rozpocząć od przedstawienia pewnych elementów współczesnego kontekstu uprawiania nauki i jej funkcjonowania w społeczeństwie, które pozwolą uwypuklić racje stojące u podstaw tytułowego wezwania do ofensywy.

Pierwszy z nich to rozbieżność między prawnym i instytucjonalnym ujęciem nauki a faktycznie prowadzonymi badaniami. W tych pierwszych akceptowany jest izolacjonizm metodologiczny, którego istotę można przedstawić następująco: problemy badawcze da się postawić w ramach konkretnej dyscypliny, rozwiązać i uzasadnić metodami tej dyscypliny oraz

${ }^{1}$ C. Fehr, K.S. Plaisance, Socially relevant philosophy of science: An introduction, „Synthese” 177/2010, s. 302 (tłum. A. L.-K.). 
ocenić rozwiązanie zgodnie z jej kryteriami. Inne dyscypliny mogą oczywiście z tego rozwiązania korzystać, i można też tworzyć nowe dyscypliny. Jest to pewna wersja reguły NOMA (non-overlapping magisterium), którą Stephen J. Gould sformułował dla ujęcia relacji między nauką i religią. Reguła NOMA głosi, że każdy obszar badawczy formułuje własne reguły stawiania pytań i ustala własne kryteria sądzenia i rozstrzygania, a przyjęte standardy i procedury rozwinięte w celu rozważania i rozstrzygania uprawnionych kwestii definiują magisterium, czyli nauczycielski autorytet w danym obszarze. Na dyscypliny należy patrzeć jak na obrazy w galerii sztuki - jako dzieła zamknięte w solidnych ramach². Takie właśnie ujęcie przyjmuje polskie prawo. Art. 1.1. ustawy o stopniach naukowych i tytule naukowym oraz o stopniach i tytule w zakresie sztuki głosi: „Stopniami naukowymi są stopnie doktora i doktora habilitowanego określonej dziedziny nauki w zakresie danej dyscypliny naukowej”3. Posiadanie stopni czy tytułów naukowych z danej dyscypliny jest niezbędne do zaliczenia badacza do tzw. minimów programowych, umożliwiających prowadzenie kierunku. Z kolei rozporządzenie Ministra Nauki i Szkolnictwa Wyższego z dnia 8 sierpnia 2011 r. wprowadza nie dwu-, ale trójstopniowy podział nauki na: obszary, dziedziny i dyscypliny4. Ów podział jest istotny z punktu widzenia funkcjonowania jednostek dydaktycznych i badawczych. Na przykład art. 3 Prawa o szkolnictwie wyższym z dnia 27 lipca 2005 r. ustala, że wyraz „uniwersytet” może być używany w nazwie uczelni, której jednostki organizacyjne posiadają uprawnienia do nadawania stopnia naukowego doktora co najmniej w dziesięciu dyscyplinach, w tym co najmniej po dwa uprawnienia w każdej z podanych grup dziedzin nauki ${ }^{5}$. Podejście dyscyplinarne determinuje organizację nauki jako instytucji społecznej, jak się wydaje, nie tylko w Polsce.

Dyscyplinarne ujęcie nauki jest w konflikcie z co najmniej od ćwierć wieku istniejącym trendem - transdyscyplinarnością badań naukowych ${ }^{6}$. Ce-

${ }^{2}$ S.J. Gould, Skały wieków. Nauka i religia w pełni życia, Zysk i S-ka, Poznań 2002.

3 Dz.U. z 2003 r., nr 65, poz. 595, http://www.dn.uj.edu.pl/documents/1333504/3092 436/2003_tekst_jednolity_ustawa_\%20o_stopniach_nauk.pdf [31.12.2014].

${ }^{4}$ Dz.U. nr 179, poz. 1065, ss. 10427-10429, http://isip.sejm.gov.pl/DetailsServlet? id=WDU20111791065 [2.01.2015]. W analizach pomijam obszar sztuki.

${ }^{5}$ Dz.U. nr 164, poz. 1365, http://prawo.ws/o_szkolnictwie_wyzszym/art3.htm [2.01. 2015].

${ }^{6}$ Jest to Mode 2 Science. Zob. H. Novotny, C. Limoges, P. Scott, M. Gibbons, The New Production of Knowledge: The Dynamics of Science and Resarch in Contemporary Societies, Sage, London 1994; H. Novotny, P. Scott, M. Gibbons, „Mode 2” revisited: The New Production of Knowledge, „Minerva” 41/2003, ss. 179-194. 
chą charakterystyczną badań transdyscyplinarnych jest „mobilizacja” całego zespołu perspektyw teoretycznych i różnych metodologii do postawienia i rozwiązania problemu. W przeciwieństwie do badań multidyscyplinarnych i interdyscyplinarnych owe perspektywy nie muszą pochodzić z uznanych dyscyplin czy też prowadzić do wytworzenia się nowej dyscypliny. Stawiane są trzy typy pytań badawczych: (a) Jakie procesy wygenerowały problem i ewentualnie mogą wpłynąć na jego dalszy rozwój (system knowledge)?; (b) Jakiej wiedzy poszukujemy (target knowledge)?; (c) Jak dana sytuacja problematyczna może zostać zmieniona i ulepszona - ku czemu dążymy (transformation knowledge)? Uzyskana wiedza nie jest sumą podejść dyscyplinarnych. Rozwiązania zawierają elementy empiryczne i teoretyczne, są więc faktycznym wkładem w wiedzę naukową, choć wiedzy uzyskanej w badaniach transdyscyplinarnych nie da się „rozparcelować” na poszczególne dyscypliny; nie da się też uzyskać transdyscyplinarnego stopnia naukowego. Rodzi się natomiast problem oceny jakości badań i ich rezultatów, ponieważ nie ma stabilnej taksonomii dyscyplin, z których moglibyśmy czerpać recenzentów. Trwa obecnie burzliwa dyskusja, na czym polega transdyscyplinarność badań naukowych; czy badania takie powinny zastąpić, czy też jedynie uzupełnić badania w ramach dyscyplin; jakie są konsekwencje rozumienia nauki jako zbioru badań transdyscyplinarnych ${ }^{7}$. To, co jest jednak ważne dla uzasadnienia tytułowego wyzwania do ofensywy, to istnienie badań transdyscyplinarnych i nadzieje w nich pokładane. Transdyscylinarność jest bowiem wymuszana naturą problemów. Projekty transdyscyplinarne mają na celu wypracowanie rozwiązań skomplikowanych problemów życiowych, a nie jedynie odpowiedzi na wąskie, faktualne pytania ${ }^{8}$. Do takich problemów należą zmiany klimatyczne, zrównoważony rozwój i ochrona środowiska naturalnego.

Drugim elementem współczesnego - zresztą nie tylko współczesnego - kontekstu uprawiania nauki jest przekonanie o wiodącej roli wiedzy naukowej w postępie cywilizacyjnym. Wprost zostało ono wyrażone w ra-

${ }^{7}$ H. Hadorn i in. (red.), Handbook of Transdisciplinary Research, Springer, Heidelberg 2008.

${ }^{8}$ Można to uznać za realizację postulatu Nicholasa Maxwella o przejście od badania-dla-wiedzy do badania-dla-mądrości. Zob. np. N. Maxwell, How universities can help to create a wiser world. The urgent need for an academic revolution, Imprint Academic, Exeter 2014. Maxwell twierdzi: „Podstawowym celem badania-dla-mądrości jest mądrość rozumiana jako możność i aktywna chęć zrealizowania tego, co w życiu wartościowe dla siebie i dla innych, a mądrość włącza wiedzę, techniczne »jak «, rozumienie i wiele innych rzeczy”. Ibidem, s. 22. 
porcie pt. Science - the endless frontier, przygotowanym w 1945 r. przez Vannevara Busha dla prezydenta USA ${ }^{9}$. W raporcie tym Bush przedstawił projekt relacji między nauką a społeczeństwem, która później została nazwana społecznym kontraktem dla nauki. Streszczenie rozpoczynające ów raport nosi tytuł, który dobrze oddaje jego główną myśl: „Postęp naukowy jest kluczowy” - wiedza naukowa jest bowiem warunkiem koniecznym rozwoju istotnych obszarów życia społecznego (zdrowie, bezpieczeństwo, gospodarka). Zasadnicze pytanie brzmi natomiast: Jak wiedza naukowa „przekłada się” na społeczne korzyści? Odpowiedź na nie wskazuje trzeci ważny element omawianego kontekstu uprawiania nauki.

W raporcie Busha przyjęty został prosty model linearny: finansowanie publiczne i prywatne $\rightarrow$ badania podstawowe $\rightarrow$ rezerwuar wiedzy $\rightarrow$ badania stosowane $\rightarrow$ rozwój $\rightarrow$ konkretne korzyści dla społeczeństwa. Panuje obecnie zgoda co do nieadekwatności modelu liniowego, ale jego zakwestionowanie miałoby wiele konsekwencji dla rozumienia nauki. Po pierwsze, nie chodzi jedynie o to, że nie ma prostego przejścia od badań podstawowych do konkretnych korzyści, wobec czego menedżerowie badań stoją przed wyzwaniem takiego organizowania badań, by lepiej odpowiadały na społeczne problemy i potrzeby, ale o to, że zwiększają się szkodliwe efekty rozwoju naukowo-technicznego. Ulrich Beck, charakteryzując współczesne społeczeństwo, nazywa je społeczeństwem ryzyka, przy czym to, co rozumiemy przez ryzyko, jest w dużej mierze produktem nauki i techniki, choć to właśnie nauka i technika są w stanie pokazać, iż mamy do czynienia z ryzykiem ${ }^{10}$. Konieczność równoważenia korzyści i ryzyka to relatywnie nowy problem w uprawianiu nauki. W dokumencie Organisation for Economic Co-operation and Development (OECD), zatytułowanym Science and Innovation Policy. Key Challenges and Opportunities, zagwarantowanie udziału nauki w rozwiązywaniu ważnych problemów społecznych, szybszego i efektywniejszego przejścia od badań do innowacji oraz minimalizacji ryzyka jest traktowane jako jedno z najważniejszych wyzwań, przed którym stoi zarządzanie nauką i techniką ${ }^{11}$. Po drugie, podział na badania podstawowe i stosowane, obecny implicite w modelu liniowym, okazuje się nieadekwatny do tego, jak faktycznie organizowane są badania naukowe.

\footnotetext{
${ }^{9}$ https://www.nsf.gov/od/lpa/nsf50/vbush1945.htm [17.12.2014].

${ }^{10}$ U. Beck, Społeczeństwo ryzyka. W drodze do innej nowoczesności, Scholar, Warszawa 2002.

${ }^{11}$ OECD, Science and Innovation Policy. Key Challenges and Opportunities, Paris, 2014, zwłaszcza Introduction (ss. 5-16), http://www.oecd.org/science/inno/23706075.pdf [29.12.2014].
} 
Maciej Grabski wyraża to w następujący sposób:

[...] z punktu widzenia nauki jej kategoryzacja na badania podstawowe i stosowane niczemu już dzisiaj nie służy, poza rozgrywkami między poszczególnymi dyscyplinami nauki. Dlatego coraz częściej mówi się po prostu o Badaniach i Rozwoju (R\&D) $)^{12}$.

Badania (a w każdym razie ich większość) prowadzone są od razu w kontekście aplikacji, tj. jako rozwiązanie problemu praktycznego czy zaspokojenie potrzeby, a nie jedynie jako odpowiedź na czysto faktualne pytanie. Po trzecie, w modelu liniowym „rezerwuar wiedzy” izolował naukę od społeczeństwa, a jednocześnie gwarantował nauce poznawczą i instytucjonalną autonomię. Obowiązywała zasada: science provides, society applies - nauka dostarcza, społeczeństwo stosuje. Uznanie nauki i techniki za źródło ryzyka i odrzucenie podziału na badania podstawowe i stosowane zmieniło relacje między nauką a społeczeństwem - model odrębnych podmiotów został zastąpiony rozmaitymi wersjami modeli partycypacyjnych. To kontekst aplikacji stanowi środowisko, w którym rodzą się naukowe problemy, rozwijane są metody, rezultaty są rozpowszechniane, a sposoby użycia definiowane. Jest to inne środowisko niż teoretyczno-eksperymentalne zdobywanie wiedzy, która następnie stosowana jest do rozwiązywania konkretnego problemu. Kontekst ten budowany jest w procesie komunikacji pomiędzy różnymi interesariuszami, którzy wnoszą swój punkt widzenia. Interesariuszami są nie tylko naukowcy i bezpośredni sponsorzy badań, ale też ci, którzy z jakichś powodów są zainteresowani rozwiązaniem problemu, którzy ponoszą koszty i ryzyko prowadzenia badań oraz konsekwencje wdrożenia rozwiązań w życie. W dialogu między nimi następuje sformułowanie problemu i jego operacjonalizacja, ustalane są procedury badawcze i analizowane konsekwencje zdobycia, rozpowszechniania i zastosowania wiedzy. Środowiskiem dialogu jest agora zaludniona rozmaitymi organizacjami, a nie jedynie „rynek” w sensie ekonomicznym.

Scharakteryzowane powyżej elementy współczesnego kontekstu uprawiania nauki są traktowane są jako wyzwania, przed którymi stają rządy, społeczeństwa i organizacje międzynarodowe ${ }^{13}$. Jak ów kontekst wpływa na status filozofii, humanistyki i nauk społecznych oraz rozumienie ich roli w badaniach w naukach przyrodniczych i technicznych?

${ }_{12}$ M.W. Grabski, Między rzq̨dem i naukq - źródła konfliktów, „Nauka” 4/2004, s. 32.

13 OECD, Governance of Public Research: Toward Better Practices, Paris, 2003; OECD, Science and Innovation Policy..., ss. 6-7. 


\section{Nauki przyrodnicze i techniczne - badania w nowym kontekście}

W przywołanym wyżej rozporządzeniu Ministra Nauki i Szkolnictwa Wyższego dziedzina: nauki humanistyczne należy (obok dziedziny: nauki teologiczne) do obszaru nauk humanistycznych, filozofia jest jedną z dyscyplin należących do dziedziny nauk humanistycznych, a nauki społeczne tworzą dziedzinę w ramach obszaru nauk społecznych (obok nauk ekonomicznych i nauk prawnych). Pozostałe pięć obszarów (nie licząc obszaru sztuki) obejmują dziedziny i dyscypliny, które potocznie traktujemy jako nauki matematyczno-przyrodnicze, techniczne i medyczne. Jest ich nie tylko więcej, ale i uchodzą za ważniejsze - bardziej użyteczne społecznie, bardziej naukowe, bardziej ścisłe; są lepiej finansowane, a kryteria oceny projektów badawczych, czasopism i indywidualnych naukowców są przystosowane do tychże „nauk ścisłych”. Filozofia, nauki humanistyczne i społeczne są naukami (figurują przecież w wykazach ministerialnych), ale jakby gorszymi - szansę na uznanie za „prawdziwą naukę” mają co najwyżej nauki społeczne, gdy są uprawiane na wzór nauk przyrodniczych. W Polsce toczy się na ten temat ożywiona dyskusja, a rozmaite postulaty sprowadzają się do żądania uwzględnienia w finansowaniu i ocenie specyfiki filozofii, humanistyki i nauk społecznych ${ }^{14}$. Tymczasem scharakteryzowane wyżej zmiany kontekstu uprawiania nauki pozwalają postawić mocniejszą tezę: nie chodzi jedynie o specyfikę, ale o niezbywalność tych dziedzin dla badań w naukach przyrodniczych i technicznych. By tę tezę zobrazować, przedstawię kilka przykładów.

Wcześniej pokazałam, że współczesne badania rozpoczynane są od razu w kontekście aplikacji - chodzi o rozwiązanie życiowo doniosłych problemów, a nie po prostu zdobycie wiedzy, która potem może być zastosowana. Czym jest problem naukowy w tym kontekście? Splatają się tu dwa rozumienia: metodologiczne - pytanie, na które nie jest znana odpowiedź, i jej poszukiwanie wymaga badań, oraz potoczne - kłopot, trudność, coś, co doskwiera. Przyjmijmy, że owym „kłopotem” jest zanieczyszczenie rzeki w pewnym regionie. Na pierwszy rzut oka jest to problem dla nauk przyrodniczych: ustalenie stopnia zanieczyszczenia oraz wskazanie (lub wyprodukowanie) substancji zdolnej te zanieczyszczenia usunąć. Rzecz

${ }_{14}$ Zob. np. http://www.praktykateoretyczna.pl/postulaty-programowe-komitetu-kryzysowego-humanistyki-polskiej/ [1.01.2015]. 
nie jest jednak taka prosta. Przed uruchomieniem badań nad oczyszczeniem wód w danym regionie należy postawić wiele pytań i przyjąć wiele założeń, które bynajmniej nie należą do nauk przyrodniczych i technicznych.

Na czym polega problem? Jeśli mówimy o zanieczyszczeniu wód w jakimś regionie, to powołujemy się na dane pochodzące z badań przyrodniczych. Jednakże owe dane mówią o stężeniach, a nie o zanieczyszczeniu. „Zanieczyszczenie” jest terminem opisowo-wartościującym - opisuje pewien stan rzeczy, a zarazem wartościuje go jako niepożądany i do zlikwidowania, stanowiący ryzyko bądź co najmniej wymagający monitorowania. Uznanie danego stężenia pewnej substancji za zanieczyszczenie wymaga więc wydania oceny, a ocena ta nie jest rezultatem badań stężenia substancji.

Dlaczego jest to problem? Odpowiedź na pierwszy rzut oka wydaje się oczywista - zanieczyszczenie powoduje wymieranie ryb, zatruwanie okolicznych pól, pociąga za sobą zakaz kąpieli, powoduje choroby mieszkańców, także ich strach i decyzje o wyprowadzeniu się z regionu. Stwierdzenie wymienionych zjawisk wymaga badań nie tylko przyrodniczych, ale także medycznych, psychologicznych czy socjologicznych. Bez wyników tych badań nie uda się bowiem uzasadnić twierdzenia, że mamy do czynienia z problemem wartym rozwiązania.

Jaka jest waga tego problemu na tle innych? Jakie będą konsekwencje (koszt) nierozwiązania tego problemu? Można stawiać np. hipotezy o upadku regionu, wzroście zachorowań, a więc i zwiększeniu kosztów medycznych. Także i w tym przypadku potwierdzenie lub obalenie hipotez nie jest sprawą jedynie nauk przyrodniczych.

Takich pytań można postawić więcej, ale już powyższa analiza pokazuje, że ustalenie, iż coś jest problemem wartym rozwiązania, wymaga współpracy wielu nauk; a współpraca ta nie sprowadza się jedynie do opisania zjawiska z punktu widzenia i w języku danej dyscypliny naukowej. Co więcej, w uprawianiu nauki zaczyna dominować model partycypacyjny w postawienie i rozwiązanie problemu potencjalnie zaangażowani są wszyscy interesariusze. Już na etapie postawienia problemu - w tym przypadku zanieczyszczenia wód w pewnym regionie - ich wartości, oczekiwania i obawy powinny więc być włączone w rozumienie, na czym polega problem i jego waga.

Rola interesariuszy jest jeszcze bardziej widoczna, gdy rozpoczynają się badania zmierzające do rozwiązania problemu. Badania muszą bowiem odpowiedzieć na co najmniej trzy pytania. Pierwsze z nich to pytanie o genezę problemu: Jakie procesy wywołały problem i mogą ewentualnie wpłynąć na jego dalszy rozwój? Rzecz jest stosunkowo prosta, gdy zanieczyszczenie po- 
wodują produkty uboczne technologii użytej w okolicznej fabryce, wylewane wprost do rzeki. A jeśli „,same w sobie” produkty te są nieszkodliwe (kolejny termin opisowo-wartościujący), ale reagują z równie „nieszkodliwymi” pestycydami, używanymi przez okolicznych rolników, a efektem tej reakcji jest substancja, która powoduje rozkład rośliny wodnej, czego produktem jest substancja uznana za zanieczyszczenie? Kto wobec tego powoduje zanieczyszczenie? Można oczywiście mnożyć trudności, ale już to wystarczy, by pokazać, że niekiedy istnieje niepewność co do genezy problemu, która jest pochodną interpretacji problemu, a interpretacja jest zależna od potrzeb i wartości interesariuszy zaangażowanych w rozwiązanie problemu. Kolejne pytanie powoduje jeszcze większe komplikacje: Jaki stan uznamy za zadowalające rozwiązanie problemu? Opis stanu, który chcemy osiągnąć, determinuje odpowiedź na pytanie, jakiej wiedzy poszukujemy i co faktycznie będziemy badać. Należy wobec tego ustalić, jakie wartości i normy muszą zostać uwzględnione przy wyznaczaniu celów badawczych, jakie aspekty problemu są ważne, a jakie można pominąć, co można zaryzykować, a co należy chronić, wybierając rozwiązanie, jakie konsekwencje implementacji rozwiązania możemy przewidzieć i zaakceptować, a jakie uznać za niedopuszczalne ryzyko. Czy chodzi nam o całkowite pozbycie się zanieczyszczenia, czy tylko częściowe? Czy pozbycie się zanieczyszczenia jest ważniejsze niż utrzymanie produkcji? Czy ginięcie pijawek w zanieczyszczonej rzece jest ważne, czy też można się z tym pogodzić, o ile nie giną np. raki i ryby? Trudno się spodziewać, że na te pytania odpowie chemik czy biolog w ramach swojej dyscypliny. Możemy więc mieć do czynienia z pluralizmem wartości i norm, związanych z interesariuszami projektu badawczego i zależnych od rozumienia problemu, relacji między składnikami problemu oraz faktycznie dostępnych opcji zmiany. Trzecie pytanie brzmi: Jak dana sytuacja problematyczna może zostać zmieniona i ulepszona w świetle pożądanego stanu rzeczy? I tu także pytamy ostatecznie o wartości, które muszą zostać uwzględnione przy ustalaniu „dobrego” rozwiązania.

Powyższe rozważania prowadzą do wniosku, że projekt badawczy, którego celem miałoby być rozwiązanie życiowego problemu zanieczyszczenia rzeki, nie może zostać przygotowany tylko w ramach jednej dyscypliny czy dziedziny, ale nawet w ramach jednego obszaru nauk przyrodniczych i technicznych. Co najwyżej można tworzyć takie pozory, przyjmując niejawnie - być może i nieświadomie - pojęcia i tezy z innych nauk albo po prostu potoczne czy zdroworozsądkowe przekonania.

Przyjrzyjmy się jeszcze jednemu przykładowi. Twierdzenie, że badania naukowe przynoszą konkretne korzyści społeczne, jest nadal w mocy, 
chociaż - jak pokazałam, charakteryzując współczesny kontekst uprawiania nauki - dostrzeżone zostają ryzyka związane z postępem naukowo-technicznym. Nauka - jak powszechnie się podkreśla - dostarcza rozwiązań, które są stosowane w konkretnych sytuacjach problemowych. Nancy Cartwright jednak uważa, iż jest to błędne rozumienie roli nauki ${ }^{15}$. Przyjmuje się - twierdzi - że nauka produkuje rozwiązania typów problemów, które to rozwiązania - trwałe i jednoznaczne - „spoczywają na półce”, by zostać wykorzystane w rozmaitych kontekstach. Przykładamy wielką wagę do testowania twierdzeń nauki, gdyż traktujemy to jako kwestię rzetelności wiedzy, ale niewiele zajmujemy się tym, jak owe twierdzenia są faktycznie wykorzystywane. Jak wobec tego przechodzimy od eksperymentów do zastosowania ich rezultatów? Cartwright analizuje przykład przedstawiony przez Jerry'ego Ravetza: oto mamy znakomite potwierdzenie (testy losowe, testy w terenie), że pewien nawóz jest bardzo skuteczny i zarazem bezpieczny. Wysyłamy ten nawóz w workach z instrukcją w języku angielskim do dalekiego kraju z radykalnie różną strukturą geologiczną i bez kultury używania nawozów. Nawóz zostaje zastosowany tuż przed ogromnymi opadami deszczu, przekraczającymi dziesięciokrotnie „opady” stosowane przy testowaniu bezpieczeństwa. W efekcie rzeka zostaje zatruta, ludzie chorują, zwierzęta umierają, a plony zbóż bynajmniej nie stają lepsze. Twierdzenia nauk przyrodniczych dotyczące skuteczności i bezpieczeństwa nawozu konkluduje Cartwright - są uzasadnione metodami nauk przyrodniczych. Jednakże implementacja „tych samych” rezultatów rzadko jest czystym procesem kierowanym przez nauki przyrodnicze. W implementację zaangażowane są procesy społeczne. Laboratoryjne testy bezpieczeństwa czy efektywności pewnej substancji nie mogą dostarczyć uzasadnienia twierdzeniu, że substancja ta, zastosowana „tu i teraz”, będzie efektywna i bezpieczna; potrzebujemy „testów” w miejscu, gdzie będzie ona stosowana, a testy takie będą mocno osadzone w kontekście społecznym, co wymaga współpracy nauk społecznych - nawet stwierdzenie, co właściwie chcemy zbadać. Hugh Lacey postawił tezę jeszcze bardziej radykalną: błędnie zakładamy, że zjawisko w laboratorium zawsze jest „tym samym” zjawiskiem, co w realnym świecie, i operujemy tym zjawiskiem tak, jak gdyby posiadało tylko te konsekwencje, które obserwujemy w laboratorium. Tymczasem tak nie jest ${ }^{16}$.

15 N. Cartwright, Well-ordered science: Evidence for use, „Philosophy of Science” 73/ 2006, ss. 981-990.

${ }^{16} \mathrm{H}$. Lacey, Is science value free? Values and scientific understanding, Routledge, London - New York 1999. 


\section{Ofensywa filozofii, humanistyki i nauk społecznych - argumenty za}

Przedstawione wyżej analizy projektu badawczego, wstępnie przypisanego naukom przyrodniczym i technicznym, oraz wykorzystania naukowo-technicznych rozwiązań pokazują, że w trakcie badań i implementacji ich wyników pojawiają się terminy, których nie sposób interpretować bez odwołania się do filozofii, humanistyki czy nauk społecznych, jak również pytania, na które nie można odpowiedzieć bez odwołania się do tychże typów ${ }^{17}$ wiedzy. Co więcej, pojawiają się w nich wartości pozaepistemiczne, wnoszone do formułowania i rozwiązania problemu badawczego przez różne grupy interesariuszy. Dobrze tę sytuację wyraził Ulrich Beck, pisząc o społeczeństwie ryzyka:

Konstatacje ryzyka to forma, w jakiej etyka, a przez to filozofia, kultura, polityka rodzą się na nowo - w centrach modernizacji - w gospodarce, w naukach przyrodniczych i dyscyplinach technicznych. Zwrócenie uwagi na ryzyko wynika z jeszcze nierozpoznanej, nierozwiniętej symbiozy nauk przyrodniczych i humanistycznych, symbiozy racjonalności życia codziennego i racjonalności ekspertów, interesu i faktów. [...] Niemożliwa jest już wyizolowana specjalizacja, nie można określać ryzyka wyłącznie według standardów własnej racjonalności. Konstatacje ryzyka zakładają współdziałanie ponad dyscyplinami, grupami obywateli, przedsiębiorstwami, administracją i polityką ${ }^{18}$.

„Ryzyko” jest terminem często używanym w szeroko rozumianym dyskursie społecznym i dlatego dobrze ilustruje argument na rzecz tytułowej ofensywy - aby nauka przynosiła pożądane rezultaty poznawcze, społeczne i techniczne, a nie powodowała negatywnych konsekwencji, badania w naukach przyrodniczych i technicznych muszą być prowadzone we współpracy z filozofią, humanistyką i naukami społecznymi. Wskazywanie podstaw i zasad takiej współpracy widziane jest nawet jako kluczowy cel badań nazywanych społecznie istotną filozofią nauki (socially relevant philosophy of science). Nie chodzi więc jedynie o uwzględnienie w prawie i polityce naukowej specyfiki dziedzin i dyscyplin nauki, ale o ich współpracę przy rozwiązywaniu problemów. Beck żąda zresztą nie tylko współpracy, ale

${ }^{17}$ Używam terminu „typ wiedzy”, by uniknąć odniesień do terminologii ministerialnej oraz możliwych nieporozumień.

${ }^{18}$ U. Beck, Społeczeństwo ryzyka..., s. 39. 
i symbiozy. Takich terminów jak ryzyko jest zresztą wiele: zanieczyszczenie, bezpieczeństwo, patologia, bezrobocie, innowacja, korzyść.

Drugi argument odwołuje się do tego, że współczesna nauka uprawiana jest w schematach partycypacyjnych, tj. w postawieniu i rozwiązaniu problemów życiowych uczestniczą różne grupy interesariuszy. Jeśli naukowcy mają być interesariuszami - a nie jedynie „umysłami do wynajęcia”, realizującymi zlecenia tych, którzy mają dość władzy (politycznej, finansowej, administracyjnej), by zainicjować badania, i nietroszczącymi się o cele, zastosowania i konsekwencje zastosowania wyników - muszą być w stanie uchwycić szeroko rozumiany kontekst własnych badań, również jego wymiar aksjologiczny; podobnie inne grupy społeczne muszą być w stanie uchwycić problem (także ryzyko) i związane z nim wartości, jak też określić warunki „dobrego rozwiązania”, jeśli mają być interesariuszami, a nie jedynie konsumentami czy ofiarami rozwoju naukowo-technicznego. Warunkiem stania się interesariuszem, zdolnym do komunikacji z innymi interesariuszami, jest właściwa edukacja, wykraczająca poza specjalizację zawodową, właściwa postawa społeczno-etyczna oraz umiejętności konstruktywnego i krytycznego dialogu, łączenia perspektyw, wypracowywania priorytetów badawczych itd. Tego nie dostarczy edukacja jedynie w naukach przyrodniczych i technicznych.

Przedstawione wyżej argumenty stanowią racje uzasadniające tytułowe wezwanie do ofensywy. Zgodnie ze Słownikiem języka polskiego PWN, ofensywa to, m.in. 1. „natarcie dużych sił wojska na pozycje przeciwnika na całym froncie lub na większym jego odcinku”; 2. „zorganizowane wystąpienie przeciw komuś lub czemuś”" ${ }^{19}$. Celem ofensywy jako natarcia i zorganizowanego wystąpienia filozofii, humanistyki i nauk społecznych byłoby pokazanie dwóch rzeczy: bez filozofii, humanistyki i nauk społecznych nie da się odpowiedzialnie uprawiać nauk przyrodniczych i technicznych oraz korzystać z ich rezultatów, a bez edukacji w nich nie da się uczestniczyć w rozwoju nauki i techniki jako interesariusz, a nie jedynie jako wykonawca, konsument i ofiara. Ofensywa może przebiegać na różnych płaszczyznach: intelektualnej (przekonanie zainteresowanych do uznania roli filozofii, humanistyki i nauk społecznych w badaniach z zakresu nauk przyrodniczych i technicznych), politycznej (lobbowanie na rzecz zmiany reguł zarządzania nauką i organizacji kształcenia), badawczej (realizowanie projektów dotyczących natury nauki i jej społecznej roli).

${ }_{19}$ Słownik języka polskiego PWN, http://sjp.pwn.pl/sjp/ofensywa;2494184.html [31.12. 2014]. 
Zapewne można wymienić jeszcze inne płaszczyzny. Pocieszający jest fakt, że postulowana ofensywa rozpoczęła się mocno i wyraźnie w USA. Znamienny w tym względzie jest raport Komisji ds. nauk społecznych i humanistyki, powołanej przez American Academy of Art and Sciences. Raport ten nosi tytuł: Sedno rzeczy. Humanistyka i nauki społeczne dla [budowy] dynamicznego, ambitnego i bezpiecznego narodu. Na wstępie zaś stwierdza:

Kto poprowadzi Amerykę w jasną przyszłość? Obywatele, którzy są wykształceni w najszerszym możliwym sensie, tak że są w stanie uczestniczyć w zarządzaniu sobą i angażować się w świat; kreatywne i zdolne do przystosowania się siły produkcyjne; eksperci w zakresie bezpieczeństwa narodowego, wyposażeni w rozumienie kultury, wiedzę o dynamice społecznej i umiejętności komunikacyjne, by przeprowadzać nasze służby zagraniczne i militarne przez złożone globalne konflikty militarne; wybieralni urzędnicy i szersze społeczeństwo, które uczestniczy w obywatelskim politycznym dyskursie, ufundowanym na zrozumieniu i docenieniu sposobów, na jakie to, co nas różni, i to co nam wspólne ukształtowało i nadal kształtuje naszą bogatą historię ${ }^{20}$.

Cele są jasno zidentyfikowane:

(1) kształcenie Amerykanów w zakresie wiedzy, umiejętności i rozumienia [świata], które będą niezbędne skutecznej partycypacji w demokracji dwudziestego pierwszego wieku; (2) rozwijania innowacyjnego, silnego i konkurencyjnego społeczeństwa; (3) wyposażenie narodu w to, co niezbędne do przywództwa w świecie połączonym więzami. Te cele nie mogą być osiągnięte wyłącznie przez nauki matematyczno-przyrodnicze i techniczne ${ }^{21}$.

O tym, że współczesny nacisk na nauki medyczne, techniczne przyrodnicze (czyli science) zagraża demokracji, pisze Martha C. Nussbaum. Twierdzi ona, że edukacja młodych ludzi opierająca się na programach, które nie zawierają wystarczającej porcji filozofii, historii, literatury itp., pozwala na wykształcenie specjalistów, którzy przyczynią się do wzrostu produktu krajowego brutto, ale nie na wychowanie obywateli, ponieważ absolwentom brakuje rozumienia świata i jego przemian, odwagi i umiejętności krytycznego myślenia, empatii, czyli tego wszystkiego, co pozwala być uczestnikiem demokratycznych procesów kształtowania świata ${ }^{22}$.

${ }^{20}$ http://www.humanitiescommission.org/_pdf/hss_report.pdf [2.01.2015].

${ }^{21}$ Ibidem. Zwrotem „nauki matematyczno-przyrodnicze i techniczne” tłumaczę użyty $\mathrm{w}$ raporcie termin science.

${ }^{22}$ M.C. Nussbaum, Not For Profit: Why Democracy Needs the Humanities, Princeton University Press, Princeten 2010. 


\section{Podsumowanie}

Punktem wyjścia niniejszych rozważań były zmiany współczesnego kontekstu uprawiania nauki, tj. przejście od badań dyscyplinarnych do transdyscyplinarnych, od bezwzględnego uznania korzyści płynących z nauki do uznania ryzyka za rezultat rozwoju naukowo-technicznego, od modelu liniowego: badania podstawowe - badania stosowane - korzyści społeczne do modelu „heliksowego” splecenia niegdyś różnych badań w nierozerwalną całość, od autonomii nauki do partycypacji różnych grup interesariuszy w projektach badawczych i ustalaniu priorytetów. W tym kontekście utrzymywany jest prawny i instytucjonalny podział nauki, który filozofię traktuje jako jedną z dyscyplin humanistyki, a humanistykę i nauki społeczne jako obszary nauki, przy czym w różnych aspektach owe obszary traktowane są jako „mniej naukowe”, z wszystkimi tego konsekwencjami (np. finansowymi, administracyjnymi). Tymczasem analiza uprawiania nauki we współczesnym kontekście pokazuje, że bez współpracy - czy nawet symbiozy - nauk przyrodniczych i technicznych z filozofią, humanistyką i naukami społecznymi oraz bez wypracowania „symbiotycznego” modelu edukacji nie da się odpowiedzialnie uprawiać nauki, korzystać z jej wyników i partycypować w kształtowaniu rozwoju naukowo-technicznego. To zaś uzasadnia zawarte w tytule artykułu wezwanie do ofensywy, która pozwoliłaby „przełożyć” faktyczną funkcję filozofii, humanistyki i nauk społecznych w innych obszarach nauk na ich metodologiczny, organizacyjny i społeczny status. Do rozważenia pozostaje kwestia, czy ofensywa ta ma ów status nadać, czy raczej przywrócić.

W tle moich rozważań tkwią trzy fundamentalne pytania. Po pierwsze, po co ludzkości nauka? Czy jest ona instrumentem likwidowania bolączek i dostarczania materialnego dobrobytu, czy też jej rozwój musi być podporządkowany dobru wspólnemu? Pytania te wyraźnie pojawiają się w dyskusji nad koniecznością przygotowania nowego społecznego kontraktu dla nauki ${ }^{23}$. Po drugie, jaki jest cel edukacji, zwłaszcza uniwersyteckiej? Czy chodzi o nabycie wiedzy, umiejętności i kompetencji społecznych, by zdobyć przewagę konkurencyjną na rynku pracy, czy też o ukształtowanie

${ }^{23}$ R. Frodeman, C. Mitcham, Beyond the Social Contract Myth: Integrating Science and the Common Good, „Issues in Science and Technology” 16(4)/2000, ss. 37-41; P. Hoyningena-Huene, M. Weber, E. Oberheim, Towards a new social contract for science, „Nature and Resources” 34(4)/1998; N. Maxwell, From Knowledge to Wisdom: A Revolution in the Aims and Methods of Science, Blackwell, Oxford 1984 oraz inne książki tego autora. 
osobowości poprzez nabycie kultury intelektualnej, moralnej i estetycznej, jak postulował Tadeusz Czeżowski? Współczesna dyskusja nad rolą i statusem uniwersytetu te pytania ostro formułuje ${ }^{24}$. Po trzecie, czy realizując ową postulowaną współpracę czy symbiozę, nie uwikłamy się w niekończący się spór o definiowanie ryzyka, wartości, priorytetów badawczych? Ulrich Beck wprost wyraża taką obawę ${ }^{25}$. Obawa ta jest uzasadniona, jeśli uznamy, iż ludzki rozum nie jest w stanie dotrzeć do pryncypiów rzeczywistości, takich, które pozwoliłyby mu ocenić, co jest/nie jest prawdziwym ryzykiem i prawdziwym dobrem człowieka, społeczeństwa, a nawet ludzkości; że nie zdoła uchwycić ludzkiej natury i jej normatywnego wymiaru; że nie potrafi dostrzec moralnego statusu człowieka w relacji do innych bytów. Gdyby tak było, znaczenia takich pojęć, jak: ryzyko, bezpieczeństwo, szkoda, korzyść czy dobro osoby rzeczywiście musiałyby być ustanawiane decyzjami politycznymi - tak jak polityka w ramach „poprawności politycznej” decyduje, które słowa dla kogo są obraźliwe. Nie podejmę w tym miejscu dyskusji na temat wyrażonej przez Becka obawy. Chcę jednak podkreślić, że fundamenty owej obawy - jak i uznania obawy za bezzasadną - mają charakter filozoficzny. To zaś pokazuje, że status filozofii, jej miejsce wśród nauk i jej rola poznawcza są inne niż np. fizyki czy językoznawstwa. Traktowanie jej jako jednej z dyscyplin jest błędem zarówno poznawczym, jak i praktycznym, co szkodzi nauce jako całości oraz uniwersytetowi jako środowisku uprawiania nauki - choćby dlatego, że nikt nie realizuje zadania integracji dyscyplin, rozważenia wzajemnych związków i wkładu każdej z nich do całościowego rozumienia natury i porządku rzeczy ${ }^{26}$. Dyskusja nad tymi kwestiami wykracza poza cele przyjęte w niniejszym artykule. W mocy pozostaje natomiast wezwanie do ofensywy - jeśli uprawianie nauki ma być zajęciem sensownym i społecznie dobroczynnym.

\section{Literatura}

Beck U., Społeczeństwo ryzyka. W drodze do innej nowoczesności, Scholar, Warszawa 2002. Cartwright N., Well-ordered science: Evidence for use, „Philosophy of Science” 73/2006. Fehr C., Plaisance K.S., Socially relevant philosophy of science: An introduction, „Synthese” $177 / 2010$.

${ }^{24}$ Zob. np. A. Lekka-Kowalik, Uniwersytet jako firma usługowa. Szansa czy klęska?, „Ethos” 85-86/2009, ss. 52-69.

${ }^{25}$ U. Beck, Społeczeństwo ryzyka..., s. 39.

${ }^{26}$ Podzielam tu pogląd Alasdaira MacIntyre’a z jego książki Bóg, filozofia, uniwersytety. Wybrane zagadnienia z historii katolickiej tradycji filozoficznej, tłum. A. Łagodzka, Instytut Wydawniczy „Pax”, Warszawa 2013. 
Frodeman R., Mitcham C., Beyond the Social Contract Myth: Integrating Science and the Common Good, „Issues in Science and Technology” 16(4)/2000.

Gould S.J., Skały wieków. Nauka i religia w pełni życia, Zysk i S-ka, Poznań 2002.

Grabski M.W., Między rzq̨dem i naukq - źródła konfliktów, „Nauka” 4/2004.

Hadorn H. i in. (red.), Handbook of Transdisciplinary Research, Springer, Heidelberg 2008.

Hoyningena-Huene P., Weber M., Oberheim E., Towards a new social contract for science, „Nature and Resources” 34(4)/1998.

Lacey H., Is science value free? Values and scientific understanding, Routledge, London - New York 1999.

Lekka-Kowalik A., Uniwersytet jako firma usługowa. Szansa czy klęska?, „Ethos” 85-86/ 2009.

MacIntyre A., Bóg, filozofia, uniwersytety. Wybrane zagadnienia z historii katolickiej tradycji filozoficznej, tłum. A. Łagodzka, Instytut Wydawniczy „Pax”, Warszawa 2013.

Maxwell N., From Knowledge to Wisdom: A Revolution in the Aims and Methods of Science, Blackwell, Oxford 1984.

Maxwell N., How universities can help to create a wiser world. The urgent need for an academic revolution, Imprint Academic, Exeter 2014.

Novotny H., Limoges C., Scott P., Gibbons M., The New Production of Knowledge: The Dynamics of Science and Resarch in Contemporary Societies, Sage, London 1994.

Novotny H., Scott P., Gibbons M., „Mode 2” revisited: The New Production of Knowledge, „Minerva” 41/2003.

Nussbaum M.C., Not For Profit: Why Democracy Needs the Humanities, Princeton University Press, Princeton 2010.

OECD, Governance of Public Research: Toward Better Practices, Paris 2003.

OECD, Science and Innovation Policy. Key Challenges and Opportunities, Paris 2014, http://www.oecd.org/science/inno/23706075.pdf [29.12.2014].

Słownik języka polskiego PWN, http://sjp.pwn.pl/sjp/ofensywa;2494184.html [31.12.2014].

http://isip.sejm.gov.pl/DetailsServlet?id=WDU20111791065 [2.01.2015].

http://prawo.ws/o_szkolnictwie_wyzszym/art3.htm [2.01.2015].

http://www.dn.uj.edu.pl/documents/1333504/3092436/2003_tekst_jednolity_ustawa_\%20o_ stopniach_nauk.pdf [31.12.2014].

http://www.humanitiescommission.org/_pdf/hss_report.pdf [2.01.2015].

http://www.praktykateoretyczna.pl/postulaty-programowe-komitetu-kryzysowego-humanistyki-polskiej/ [1.01.2015].

https://www.nsf.gov/od/lpa/nsf50/vbush1945.htm [17.12.2014]. 